\title{
ZEOLITE MIXTURES AS ADSORPTIVE FILL MATERIAL WITH SUSTAINABLE BEARING CAPACITY
}

\author{
PATRICK S. KWON ${ }^{1}$, RAHIM SHAHROKHI ${ }^{1}$, JUNBOUM PARK ${ }^{1}$ \& HYUNGWAN KIM ${ }^{2}$ \\ ${ }^{1}$ Department of Civil and Environmental Engineering, Seoul National University, South Korea \\ ${ }^{2}$ Baum CM \& Architects, South Korea
}

\begin{abstract}
A number of industrial zones in South Korea were reported to be contaminated by heavy metals by the leachate from industrial activities. Such contamination could cause serious damage to the subsurface environment including soil and groundwater, which is often the source of our drinking water. The treatment of zeolite mixing at the bottom of such industrial zones might prevent, or at least reduce, the damage of contamination by adsorption of the heavy metals from the leakage. However, such mixtures should maintain the proper bearing capacity as a foundation fill material from the geotechnical point of view at the same time. To investigate the effect of mixtures of zeolite with local soils for the adsorption of heavy metals $(\mathrm{Zn})$ and sustainability of bearing capacity, adsorption isotherm tests and direct shear test with compaction tests were performed. Results showed that mixing the zeolite with local soils might effectively reduce the spreading of the heavy metal contamination when maintaining its proper geotechnical properties as a fill material of industrial zones.
\end{abstract}

Keywords: fill material, zeolite mixed soil, heavy metal adsorption.

\section{INTRODUCTION}

These days in South Korea due to the rapid growth of industrial factories, soil and groundwater are more susceptible to be contaminated with various kind of polluters. Especially, soil contamination of industrial zones is has become a severe problem due to its high concentration of contaminants [17], [18]. Unlike other kinds of pollution, soil contamination is hard to detect until certain damage occurs and the aspect of pollution is depended on the soil property. In South Korea, 17 materials are regulated by soil conservation law, and 8 of them is heavy metals $\left(\mathrm{As}, \mathrm{Cd}, \mathrm{Cu}, \mathrm{Cr}^{6+}, \mathrm{Pb}, \mathrm{Ni}, \mathrm{Zn}, \mathrm{Hg}\right.$ ) [14]. Heavy metals are accumulated in soil because there are not able to remove by evaporation or biodegrade. According to the Ministry of Environment of Korea, 15.3\% of the investigated industrial zones were over the warning level of contamination. The heavy metal warning and countermeasure level of soil contamination in an industrial zone is given in Table 1 [12]. Among the pollutants which are produced by the industrial complex in South Korea, zinc is the most common component (Fig. 1). For immobilizing the produced zinc of spreading into the groundwater, some adsorptive materials should be used as fill materials in industrial zones. In fact, the material which is used as fill materials in these areas should have excellent environmental protection capacity, and also bearing capacity as a sound foundation.

Natural zeolite is a hydrated mineral which is found at the considerable amount in South Korea. Due to some special characteristic of zeolite such as a negative surface area with high cation exchange capacity, and highly porous media with the large surface area, the zeolite can be a good candidate as adsorptive fill material in industrial areas. In the past years, natural zeolites have been used in a variety of applications in adsorption, soil treatment, construction industry, agriculture, and energy [10], [22].

The potential use of zeolite with relatively high values of CEC, as an amendment barrier for the purpose of increasing the adsorption capacity against contaminants, has been evaluated in several studies [4], [7], [9], [15], [22]. For example, at the study which was 
Table 1: Heavy metal warning and countermeasure level of soil contamination in South Korea. (Source: Ministry of Environment of Korea [12].)

\begin{tabular}{l||c|c}
\hline Material & Warning level $(\mathrm{mg} / \mathrm{kg})$ & Countermeasure level $(\mathrm{mg} / \mathrm{kg})$ \\
\hline \hline Cadmium & 60 & 180 \\
\hline Copper & 2,000 & 6,000 \\
\hline Arsenic & 200 & 600 \\
\hline Lead & 700 & 2,100 \\
\hline Hexavalent chrome & 40 & 120 \\
\hline Zinc & 2,000 & 5,000 \\
\hline Nickel & 500 & 1,500 \\
\hline Mercury & 20 & 60 \\
\hline
\end{tabular}

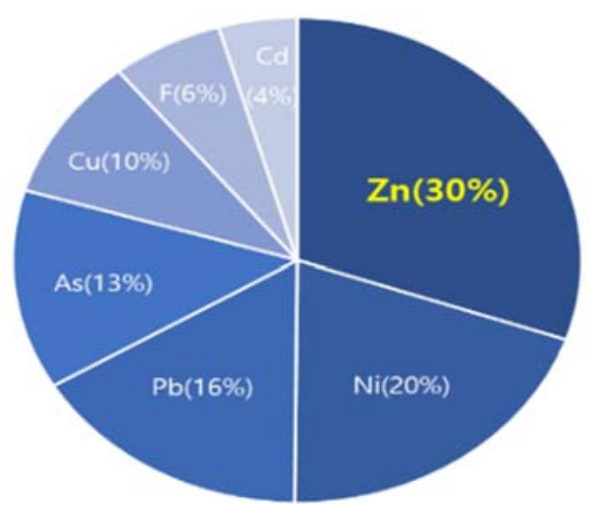

Figure 1: Investigation of soil contaminants in industrial zones of Korea. (Source: Ministry of Environment of Korea [13].)

conducted by Hong et al. [6], the effect of three kinds of zeolite was investigated to enhance the adsorption capacity of backfill amendments against two heavy metals (potassium and zinc). Their results showed amending backfill with 5\% zeolite can increase the adsorption capacity of un-amended backfill sorbent by a factor ranging from 6.2 to 7.3 for $\mathrm{K}$ and from 2.8 to 3.4 for $\mathrm{Zn}$; and also $10 \%$ zeolite amendment increased the adsorption capacity by a factor ranging from 7.5 to 13.5 for $\mathrm{K}$ and 3.1 to 3.7 for $\mathrm{Zn}$ [6]. Joanna and Kazimierz [8] have tried to evaluate the mixing of zeolite-sand media as Permeable Reactive Barrier (PRB) for protection of groundwater environment near old landfills. For this aim, the zeolite-sand mixtures containing $20 \%, 50 \%$ and $80 \%$ of zeolite (ZS20, ZS50, and ZS80) were investigated. Based on their results, the adsorption amount of $\mathrm{ZS} 80$ for $\mathrm{NH}^{+4}, \mathrm{~K}^{+}$and Fe were 100,93 and $86 \%$ respectively [8]. In the other study, the effect of zeolite amending was investigated for barrier layer against spreading lead into the soil media. For this aim, they synthesized some column experiments, and their results showed leaching of $\mathrm{Pb}$ from the treated soil was lower than the untreated soil for the first nine weeks but the trend was reversed for the final weeks of the measuring [21]. In other research, some batch experiments 
have been done to determine the adsorption capacity of clinoptilolite with respect to $\mathrm{Co}^{2+}$, $\mathrm{Cu}^{2+}, \mathrm{Zn}^{2+}$, and $\mathrm{Mn}^{2+}$. Their results demonstrated that zeolite has a great potential to remove heavy metals, and the preferential adsorption sequence for examined heavy metals by zeolite was $\mathrm{Co}_{2}+>\mathrm{Cu}_{2}+>\mathrm{Zn}^{2+}>\mathrm{Mn}^{2+}$. The achieved sorption capacities were 0.5, 0.22, 0.29 and 0.15 $\mathrm{mmol} / \mathrm{kg}$ for $\mathrm{Co}^{2+}, \mathrm{Cu}^{2+}, \mathrm{Zn}^{2+}$ and $\mathrm{Mn}^{2+}$ respectively [4]. In the study by Wijesinghe et al. [24] the effect of Australian zeolite and $\mathrm{NaCl}$ treated zeolite was investigated for removing ammonium by doing some batch experiments. The maximum adsorption capacity of both natural Australian zeolite and $\mathrm{NaCl}$ treated zeolites were estimated as 9.48 and $11.83 \mathrm{mg} / \mathrm{g}$, respectively [24]. Perić et al. [17] found that removal efficiency of natural zeolite for $\mathrm{Zn}, \mathrm{Cu}$, $\mathrm{Pb}$ was high through the batch test. Especially, under the low heavy metal concentration condition, natural zeolite could be cost-effective adsorbents for heavy metals. They mentioned that natural zeolite particles are porous, so the adsorption on natural zeolite occurs inner and outer surface of the particles and it is a complex process [17]. In the other study, Clinoptilolite was examined for removing toxic heavy metals from stormwater runoff. Batch experiment were done regard adsorbing lead, copper and zinc by Clinoptilolite. Clinoptilolite demonstrated maximum adsorption capacity of $85 \mathrm{mg} / \mathrm{g}$ for the lead, $12 \mathrm{mg} / \mathrm{g}$ for copper, and $13 \mathrm{mg} / \mathrm{g}$ for zinc [5]. One kind of natural Iranian zeolite was used to evaluate ammonium $\left(\mathrm{NH}^{4+}\right)$ removal from aqueous solutions. Batch experiments were performed as a function of $\mathrm{pH}$, adsorbent dose, contact time and temperature. The results showed the zeolite has high removal efficiency against ammonium, and the optimum conditions for the effective adsorption of $\mathrm{NH}^{4+}$ ions onto natural zeolite were found at $\mathrm{pH} 7.0$, temperature $298^{\circ} \mathrm{K}$, and contact time $30 \mathrm{~min}$ [11].

The results of the studies which have been done to evaluate the adsorption capacity of natural zeolite were promising and showed that zeolite has high removal ability against heavy metals. Considering the aforementioned results, high removal potential of zeolite against heavy metals is expected; However, as it was mentioned before, the other crucial properties of barrier backfills is maintaining good bearing capacity. Nevertheless, research studies about mechanical properties of zeolite are limited, and almost the scope of the past studies has focused on evaluating the adsorption capacity of zeolite. Therefore, by considering all of the mentioned points, the main objective of this study is divided into two part; first the adsorption capacity of zeolite is assessing for immobilizing zinc from spreading into the groundwater, and secondly, mechanical properties of zeolite will evaluate for using zeolite as adsorptive backfill material.

\section{MATERIALS AND METHODS}

\subsection{Materials}

Zeolite was taken from the Kumnong Company mine in Pohang, South Korea. The weathered soil was collected from Gwanak Mountain, Seoul, South Korea. The chemical composition of zeolite was as follows (wt. \%) $\mathrm{SiO}_{2}-62.4 ; \mathrm{Al}_{2} \mathrm{O}_{3}-13.7 ; \mathrm{Na}_{2} \mathrm{O}-2.23 ; \mathrm{Fe}_{2} \mathrm{O}_{3}-1.89$; loss of ignition - 14.78. $\mathrm{pH}$ and cation exchange capacity (CEC) of zeolite was 6.5 and 69.58 $\mathrm{meq} / 100 \mathrm{~g}$. Soil and zeolite were dried for one day at $105^{\circ} \mathrm{C}$ in an oven before mixing. Soil and zeolite were mixed with three different content ratios of zeolite $25 \%$ (SZ25), 50\% (SZ50), and 75\% (SZ75). Weathered soil and original zeolite were named SZ0 and SZ100 respectively. The particle size distribution curves of each specimen are provided as Fig. 2. The properties of test soil and zeolite is summarized in Table 2. 


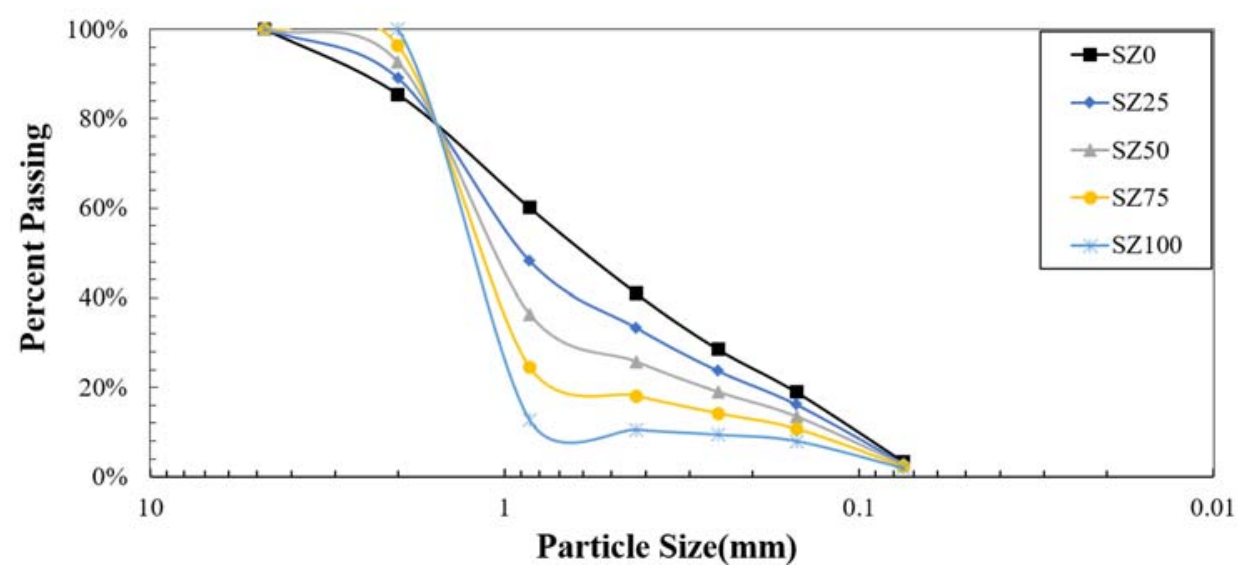

Figure 2: Particle size distribution curves of specimens.

Table 2: Summarized properties of test soil and zeolite.

\begin{tabular}{l||c|c|c|c}
\hline & $\mathrm{pH}$ & $\begin{array}{c}\text { Classification } \\
\text { (USUC) }\end{array}$ & Chemical composition & $\begin{array}{c}\text { Cation exchange } \\
\text { capacity (meq/100g) }\end{array}$ \\
\hline \hline Test soil & 7 & $\mathrm{SP}$ & - & - \\
\hline & & & $\mathrm{SiO}_{2}-62.4 ;$ & \\
Zeolite & 6.5 & $\mathrm{Al} \mathrm{O}_{3}-13.7 ;$ & 69.58 \\
& & & $\begin{array}{l}\mathrm{Na}_{2} \mathrm{O}-2.23 ; \\
\mathrm{Fe}_{2} \mathrm{O}_{3}-1.89 ;\end{array}$ & \\
& & Loss of ignition -14.78 & \\
\hline
\end{tabular}

\subsection{Methods}

\subsubsection{Adsorption batch test}

The adsorption capacity of zeolite to heavy metal was tested by using adsorption batch test. The test was performed using $3 \mathrm{~g}$ of dried material with $30 \mathrm{ml}$ of solutions containing a different concentration of zinc ions. The concentrations of solutions were 50, 125, 250, 500, $750,1000,1500,2000 \mathrm{mg} / \mathrm{L}$. The tubes were shaken by 24 hours at constant temperature $\left(20^{\circ} \mathrm{C}\right)$ and solutions containing the heavy metal ions were filtered, diluted, and then tested with AAS (Atomic Absorption Spectroscopy) for determining the remain zinc ions. The Langmuir and Freundlich isotherm equation was used to analyze the result data to determine adsorption capacity.

\subsubsection{Standard compaction and direct shear test}

The standard compaction test (ASTM D698-12) [2] was used to determine the maximum dry unit weight and optimum water content. The diameter and height of the mold are $100 \mathrm{~mm}$ and $127 \mathrm{~mm}$, respectively. The specimens are compacted with 3 layers by 25 blows of $24.47 \mathrm{~N}$ rammer dropped from $304.8 \mathrm{~mm}$. The values of maximum dry unit weight and optimum water content result from the compaction curve.

The direct shear test was performed to determine the drained shear strength of the specimens. The test was followed by the standard method of ASTM D3080 [3]. The size of 
the specimen in the shear box was $60 \mathrm{~mm}$ and $40 \mathrm{~mm}$ of diameter and height respectively. The specimens were compacted at $90 \%$ of the maximum dry unit weight by optimum water content which is the result of the standard compaction test.

\section{RESULTS AND DISCUSSION}

\subsection{Adsorption of zinc by zeolite}

After 24 hours of shaking, the concentration of zinc ion was measured by AAS. The experimental results indicate that as the amount of zeolite in the mixture increases adsorption capacity increases. Adsorption of heavy metal ions by zeolite as a function of initial concentration is shown in Fig. 3. The amount of adsorbed metal ion is defined as eqn (1)

$$
C_{s}=\left(C_{i}-C_{e}\right) \times \frac{V}{m}
$$

where $\mathrm{C}_{\mathrm{s}}$ is the amount of adsorbed metal ions onto zeolite $(\mathrm{mg} / \mathrm{g}), \mathrm{C}_{\mathrm{i}}$ is the initial concentration of solution $(\mathrm{mg} / \mathrm{L}), \mathrm{C}_{\mathrm{e}}$ is the equilibrium concentration of metal in solution $(\mathrm{mg} / \mathrm{L}), \mathrm{V}$ is the volume of the solution $(\mathrm{mL})$ and $\mathrm{m}$ is the weight of the adsorbent $(\mathrm{g})$. According to Fig. 3, the zeolite has a positive effect on adsorption heavy metals. Adding more zeolite to the soil increases the adsorption amount. The higher adsorption capacity of zeolite can be attributed to the larger surface area of zeolite than soil [1], [19].

\subsubsection{Isotherm models}

In this study, Langmuir and Freundlich isotherm equations were used to analyze the sorption. Langmuir isotherm equation is as follows

$$
\frac{C_{e}}{C_{s}}=\frac{1}{Q_{L} K_{L}}+\frac{C_{e}}{Q_{L}}
$$

where $C_{e}$ and $C_{s}$ are same values as mentioned above, $Q_{L}$ is maximum sorption capacity represents monolayer coverage of sorbent, and $\mathrm{K}_{\mathrm{L}}$ represents enthalpy of sorption. The result

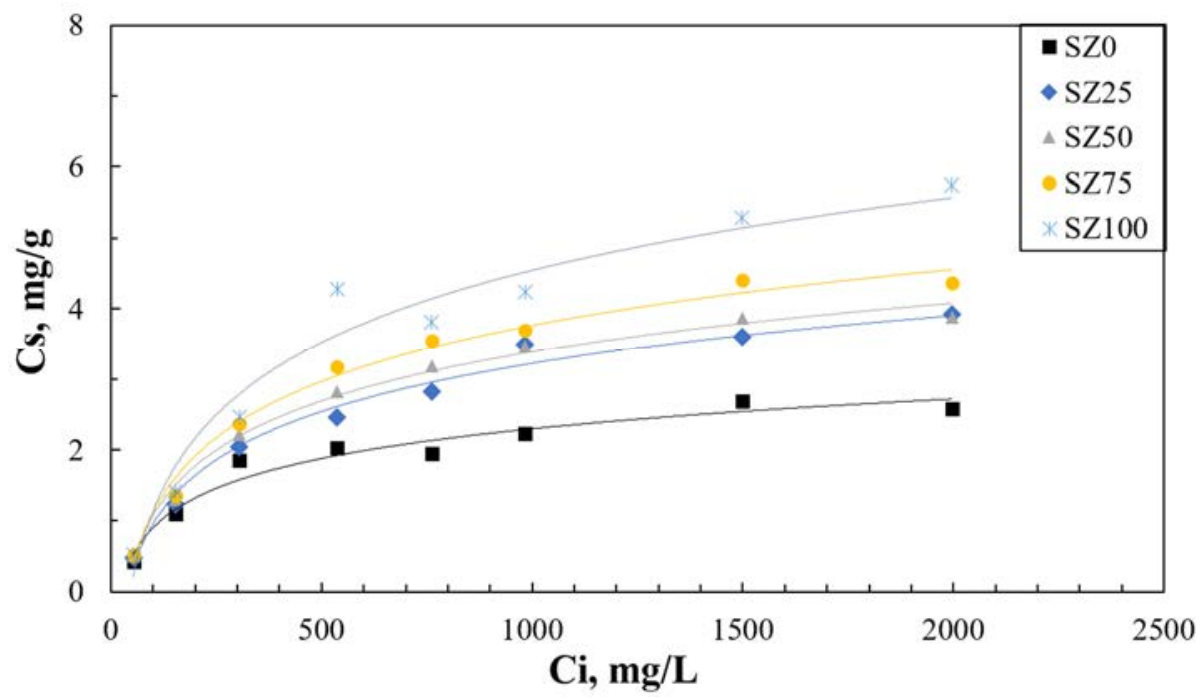

Figure 3: Adsorption of zinc onto zeolite as a function of initial concentration. 
Table 3: The result of Langmuir and Freundlich equation.

\begin{tabular}{l||c|c|c||c|c|c}
\hline \multicolumn{1}{l||}{} & \multicolumn{3}{c||}{ Langmuir model } & \multicolumn{3}{c}{ Freundlich model } \\
\hline Mixing ratio & $\mathrm{Q}_{\mathrm{L}}$ & $\mathrm{K}_{\mathrm{L}}$ & $\mathrm{R}^{2}$ & $\mathrm{~K}_{\mathrm{F}}$ & $1 / \mathrm{n}$ & $\mathrm{R}^{2}$ \\
\hline SZ0 & 2.706 & 0.010 & 0.988 & 0.281 & 0.320 & 0.882 \\
\hline SZ25 & 4.057 & 0.009 & 0.988 & 0.339 & 0.339 & 0.967 \\
\hline SZ50 & 4.024 & 0.014 & 0.996 & 0.469 & 0.309 & 0.972 \\
\hline SZ75 & 4.515 & 0.015 & 0.994 & 0.565 & 0.299 & 0.979 \\
\hline SZ100 & 5.757 & 0.013 & 0.978 & 0.670 & 0.308 & 0.953 \\
\hline
\end{tabular}

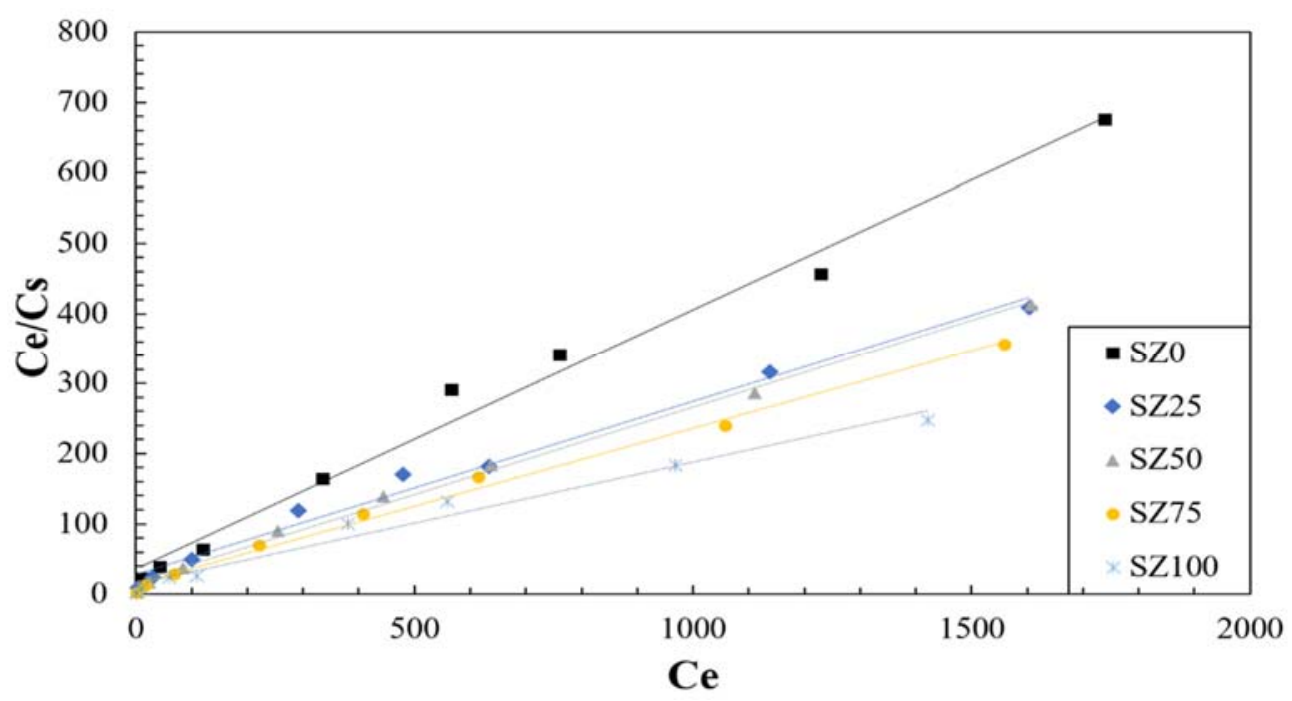

Figure 4: Linear plot of Langmuir model.

of the equation is shown in Table 3. and the linear plot obtained when $\mathrm{C}_{\mathrm{e}} / \mathrm{C}_{\mathrm{s}}$ is plotted against $\mathrm{C}_{\mathrm{e}}$ in all experimental data is shown in Fig. 4.

Freundlich isotherm equation is as follows

$$
\ln \mathrm{C}_{\mathrm{s}}=\ln \mathrm{K}_{\mathrm{F}}+1 / \mathrm{n} \ln \mathrm{C}_{\mathrm{e}}
$$

where $\mathrm{C}_{\mathrm{e}}$ and $\mathrm{C}_{\mathrm{s}}$ are same values as mentioned above, $\mathrm{K}_{\mathrm{F}}$ is Freundlich sorption coefficient which represents the ability to absorb, and $1 / \mathrm{n}$ in numerical value that indicates the strength of adsorption. The result of the equation is shown in Table 3. and the linear plot obtained when $\ln \mathrm{C}_{\mathrm{s}}$ is plotted against $\ln \mathrm{C}_{\mathrm{e}}$ in all experimental data is shown in Fig. 5.

As the result shown in Table 3, the maximum adsorption capacity has been increased when the content of the zeolite increases in both equations. The adsorption capacity analyzes by Langmuir model increase about $150 \%$ (SZ25) to $167 \%$ (SZ75) compare to the original soil (SZ0) while 121\% (SZ25) to 201\% (SZ75) by Freundlich model. For the adsorption isotherm model Langmuir model is more suitable than Freundlich since $\mathrm{R}^{2}$ values are higher. 


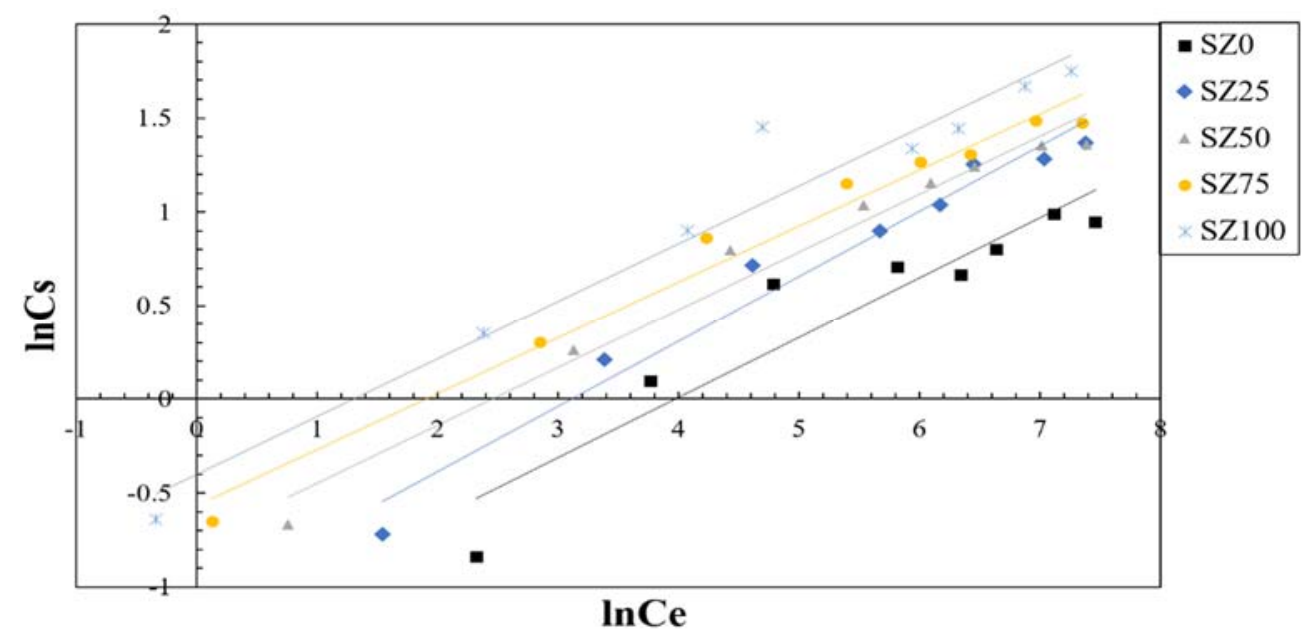

Figure 5: Linear plot of Freundlich model.

\subsection{Compaction and direct shear test}

\subsubsection{Compaction test}

Fig. 6 shows the result of the standard compaction test. The optimum water content was increased and the maximum dry unit weight decreased while the content of the zeolite increases. However, according to Korean's standards, the achieved maximum dry unit weight for all of the soil-zeolite mixtures were higher than the acceptable maximum dry unit weight $\left(1.471 \mathrm{t} / \mathrm{m}^{3}\right)$ for using as fill material [11]. The mixture shows more similar compaction characteristics of clayey soils than weathered granite soil as the amount of zeolite in the mixture increases. These results were consistent with past research, and the lower maximum dry unit weight of compacted samples with amending zeolite can be attributed to the lower density of zeolite particles and higher water hold capacity of them [20].

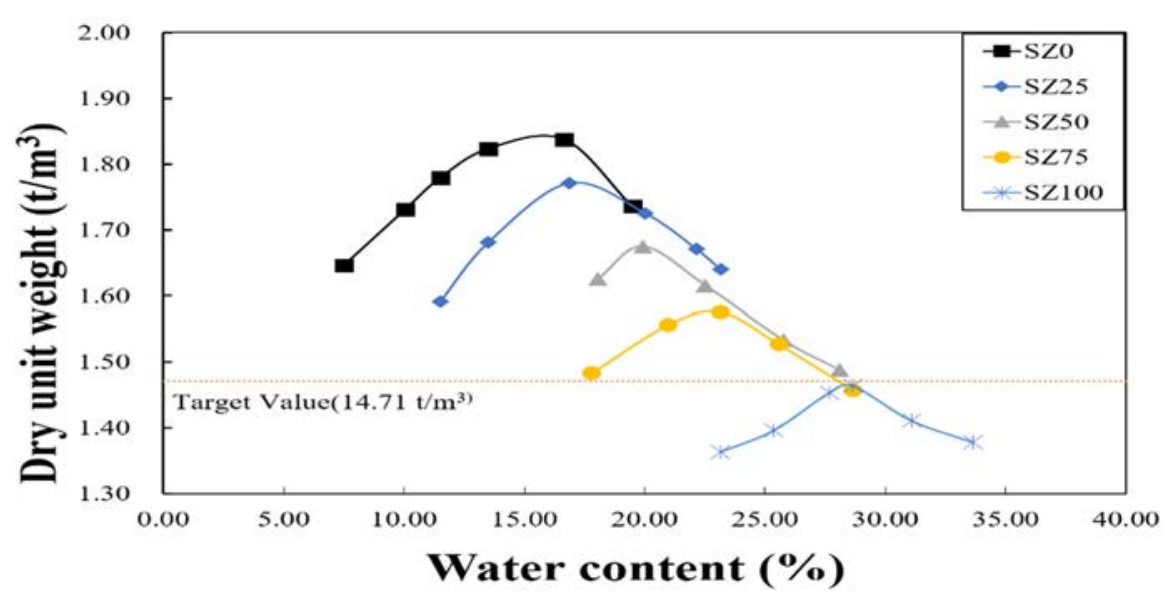

Figure 6: Compaction curves of the specimens. 
Table 4: Strength parameters of specimens.

\begin{tabular}{l||c|c|c|c|c|}
\hline & SZ0 & SZ25 & SZ50 & SZ75 & SZ100 \\
\hline \hline Friction angle $\left.{ }^{\circ}\right)$ & 40.2 & 37.3 & 35.8 & 31.7 & 31.6 \\
\hline Cohesion $(\mathrm{kPa})$ & 18.3 & 30.6 & 32.5 & 31.2 & 34.6 \\
\hline
\end{tabular}

\subsubsection{Direct shear test}

Strength parameters of the specimens are shown in Table 4. From these results, it seems the zeolite can provide higher cohesion for soil. Since zeolite is one kind of cohesive clay, so it is expected amending the soil with zeolite can increase the cohesion of soil; in the other hand, due to the clayey property of zeolite, it broke faster than soil, so zeolite shows little smaller friction angle comparing to the soil. Totally according to the Korean Design Standard for Road, the achieved shear strength parameters for all amended samples were acceptable for using as fill materials [14]. This result was consistent with other research which showed the zeolite is useful for improving the strength of expansive soils [16].

\section{SUMMARY AND CONCLUSION}

As the result shows that zeolite is more effective material to remove heavy metal than local soil, the concept of mixing soil with zeolite to make hybrid-fill material seems promising for the construction of the fill at the industrial zones. All the soil and zeolite mixtures showed $150 \%$ increment of adsorption capacity at least by Langmuir isotherm equation. All of the maximum dry weight of mixtures was satisfied by Korean regulation $\left(14.71 \mathrm{kN} / \mathrm{m}^{3}\right)$. The friction angle was above $30^{\circ}$ and cohesion value was sufficient to use as fill material. Even though all the mixtures showed sufficient adsorption capacity and strength, $25 \%$ of mixing ratio is the optimum mixing ratio from an economic perspective.

\section{ACKNOWLEDGEMENT}

This study is financed by the Korea Agency for Infrastructure Technology Advancement (KAIA).

\section{REFERENCES}

[1] Armaroli, T., Simon, L.J., Digne, M., Montanari, T., Bevilacqua, M., Valtchev, V. \& Patarin, J., Effects of crystal size and $\mathrm{Si} / \mathrm{Al}$ ratio on the surface properties of H-ZSM5 zeolites. Applied Catalysis A: General, 306, pp. 78-84, 2006.

DOI: $10.1016 /$ j.apcata.2006.03.030.

[2] ASTM D698-12, Standard test method for laboratory compaction characteristics of soil using standard effort $\left(12,400 \mathrm{ft}-\mathrm{lb} / \mathrm{ft}^{3}\left(600 \mathrm{kN}-\mathrm{m} / \mathrm{m}^{3}\right)\right), 2012$.

[3] ASTM D3080, Standard test method for direct shear test of soils under consolidated drained conditions, 2006.

[4] Erdem, E., Karapinar, N. \& Donat, R., The removal of heavy metal cations by natural zeolites. Journal of Colloid and Interface Science, 280(2), pp. 309-314, 2004. DOI: 10.1016/j.jcis.2004.08.028.

[5] Gray, C.S., Burns, S.E. \& Griffith, J.D., The use of natural zeolites as a sorbent for treatment of dissolved heavy metals in stormwater runoff. GeoCongress 2012: State of the Art and Practice in Geotechnical Engineering, pp. 3978-3987, 2012. 
[6] Hong, C.S., Shackelford, C.D. \& Malusis, M.A., Adsorptive behavior of zeolite amended backfills for enhanced metals containment. Journal of Geotechnical and Geoenvironmental Engineering, 142(7), p. 04016021, 2016.

DOI: $10.1061 /$ (asce)gt.1943-5606.0001481.

[7] Jacobs, P.H. \& Forstner, U., Concept of subaqueous capping of contaminated sediments with active barrier systems (ABS) using natural and modified zeolites. Water Research, 33(9), pp. 2083-2087, 1999. DOI: 10.1016/s0043-1354(98)00432-1.

[8] Joanna, F. \& Kazimierz, G., Evaluation of zeolite-sand mixtures as reactive materials protecting groundwater at waste disposal sites. Journal of Environmental Sciences, 25(9), pp. 1764-1772, 2013. DOI: 10.1016/s1001-0742(12)60270-8.

[9] Kayabali, K. \& Mollamahmutoğlu, M., The influence of hazardous liquid waste on the permeability of earthen liners. Environmental Geology, 39(3-4), pp. 201-210, 2000. DOI: $10.1007 / \mathrm{s} 002540050001$.

[10] Kalló, D., Applications of natural zeolites in water and wastewater treatment. Reviews in Mineralogy and Geochemistry, 45(1), pp. 519-550, 2001.

DOI: $10.2138 / \mathrm{rmg} .2001 .45 .15$.

[11] Mazloomi, F. \& Jalali, M., Ammonium removal from aqueous solutions by natural Iranian zeolite in the presence of organic acids, cations and anions. Journal of Environmental Chemical Engineering, 4(1), pp. 240-249, 2016.

DOI: $10.1016 /$ j.jece.2015.11.001.

[12] Ministry of Environment of Korea, Soil conservation law, 2014.

[13] Ministry of Environment of Korea, Investigation of soil and ground water contamination under industrial zones. http://me.go.kr.

[14] Ministry of Land, Infrastructure, and Transport of Korea, KDS 4430 00, Korean Design Standard for Road, 2016.

[15] Ören, A.H. \& Kaya, A., Factors affecting adsorption characteristics of $\mathrm{Zn}^{2+}$ on two natural zeolites. Journal of Hazardous Materials, 131(1-3), pp. 59-65, 2006. DOI: 10.1016/j.jhazmat.2005.09.027.

[16] Öncü, Ş. \& Bilsel, H., Effect of zeolite utilization on volume change and strength properties of expansive soil as landfill barrier. Canadian Geotechnical Journal, 54(9), pp. 1320-1330, 2017. DOI: 10.1139/cgj-2016-0483.

[17] Perić, J., Trgo, M. \& Medvidović, N.V., Removal of zinc, copper and lead by natural zeolite-a comparison of adsorption isotherms. Water Research, 38(7), pp. 1893-1899, 2004. DOI: 10.1016/j.watres.2003.12.035.

[18] Shang, H., Geotechnical laboratory characterization of sand-zeolite mixtures. Doctoral dissertation, University of Louisville, 2015.

[19] Shetti, V.N., Kim, J., Srivastava, R., Choi, M. \& Ryoo, R., Assessment of the mesopore wall catalytic activities of MFI zeolite with mesoporous/microporous hierarchical structures. Journal of Catalysis, 254(2), pp. 296-303, 2008.

DOI: $10.1016 /$ j.jcat.2008.01.006.

[20] Shi, W.Y., Li, H., Du, S., Wang, K.B. \& Shao, H.B., Immobilization of lead by application of zeolite: Leaching column and rhizobox incubation studies. Applied Clay Science, 85, pp. 103-108, 2013. DOI: 10.1016/j.clay.2013.08.022.

[21] Turan, N.G. \& Ergun, O.N., Removal of Cu (II) from leachate using natural zeolite as a landfill liner material. Journal of Hazardous Materials, 167(1-3), pp. 696-700, 2009. DOI: 10.1016/j.jhazmat.2009.01.047.

[22] Tuncan, A., Tuncan, M., Koyuncu, H. \& Guney, Y., Use of natural zeolites as a landfill liner. Waste Management \& Research, 21(1), pp. 54-61, 2003.

DOI: $10.1177 / 0734242 \times 0302100107$. 
100 Waste Management and the Environment IX

[23] Tsitsishvili, G.V., Androni Kashvili, T.G., Kirov, G.R. \& Filizova, L.D., Natural Zeolites, 1992.

[24] Wijesinghe, D.T.N., Dassanayake, K.B., Sommer, S.G., Jayasinghe, G.Y., Scales, P.J. \& Chen, D., Ammonium removal from high-strength aqueous solutions by Australian zeolite. Journal of Environmental Science and Health, Part A, 51(8), pp. 614-625, 2016. 